Серхій Олександрович Кірсанов (канд. техн. наук, с.н.с.) Серхій Миколайович Островський

Центральний науково-дослідний інститут Збройних Сил Украӥни, Київ, Украӥна

\title{
МЕТОДИЧНИЙ ПІДХІД ДО ОЦІНЮВАННЯ РІВНЯ АВТОМАТИЗАЦІї РОБОТИ ОРГАНІВ УПРАВЛІННЯ
}

У статті викладено методичний підхід, який дозволяє розрахувати кількості автоматизованих функиій на кожному автоматизованому робочому місиі (АРМ) та за весь орган управління (ОУ), в иілому, з неухильним дотриманням визначених вимог до показників: рівня оснащення його технічними та програмними засобами, рівня якості їх функиіонування, надійності та взаємозв'язку АРМ.

Ключові слова: автоматизоване робоче місие; технічні та програмні засоби; надійність функиіонування; рівень автоматизації задач органів управління.

\section{Вступ}

Постановка проблеми. У сучасних умовах за досвідом ведення операції Об'єднаних сил на території Донецької та Луганської областей, результатами виконання заходів оперативної підготовки ЗС України своєчасне та якісне вирішення завдань військами (силами) значною мірою залежить від ефективності управління ними.

Складовими, що обумовлюють ефективність управління військами (силами) в операціях (бойових діях) є своєчасність виконання органами управління (ОУ) функцій 3 управління та обгрунтованість рішень командувачів щодо застосування військ (сил). Значення показників складових формуються під впливом багатьох факторів, основними з яких є обсяг інформації, яка обробляється ОУ, оперативність отримання, оброблення та доведення іï до виконання [1]. При цьому, ступінь впливу зазначених факторів безпосередньо залежить від рівня автоматизації роботи посадових осіб ОУ. Але на цей час через недосконалість методичного апарату щодо визначення та оцінювання цього показника дослідити взаємозв'язок його значень зі значеннями показників своєчасності та обгрунтованості рішень неможливо. Недоліком чого постала складність у достовірному визначенні переліку функцій, які автоматизовані, 3 наступним виробленням пропозицій щодо їх нарощування.

Тому удосконалення методичного апарату щодо оцінювання рівня автоматизації роботи ОУ є актуальним науковим завданням.

Аналіз останніх досліджень і публікацій. Аналіз досліджень [2-4] дав змогу дійти висновку, що сучасні методики (методичні підходи) оцінювання рівня автоматизації роботи органів управління є розрізненими й специфічними щодо способу вирішення цього завдання та мають низку принципових недоліків.

Так, у [2] функціональний підхід щодо створення автоматизованих систем управління військового призначення потребує суттєвого доопрацювання алгоритму 3 урахуванням сучасних вимог до процесів управління. Методика [3], яка призначена для розрахунку характеристик автоматизованих систем управління, не враховує ієрархічну структуру і взаємний вплив показників оцінювання. Методика [4] дає змогу на основі експертної інформації визначити ефективність автоматизованої системи підтримки інформаційноаналітичної роботи. Проте вона не враховує особливостей визначення чисельних значень показників оцінювання роботи оперативного складу пункту управління.

У зв'язку 3 цим метою статті $є$ вирішення актуальної наукової задачі розроблення методичного підходу, який давав би змогу оцінити рівень автоматизації виконання органом управління покладених функцій, забезпечивши простоту розрахунків і незалежність результатів від умов обстановки.

\section{Виклад основного матеріалу} дослідження

Під рівнем автоматизації роботи ОУ розуміється відношення кількості автоматизованих функцій ОУ по виконанню визначених завдань до їх загальної кількості.

Сутність розробленого методичного підходу полягає у визначенні показника рівня автоматизації роботи ОУ через чітке обгрунтування за допомогою математичних співвідношень поняття “автоматизована функція” OY.

Структурно розроблений методичний підхід складається 3 шести основних етапів, представлених на рисунку 1 .

Перший етап методичного підходу передбачає формування вихідних даних для оцінювання ОУ на підставі інформації, яка міститься в формулярах на автоматизовані робочі місця посадових осіб, програмно-технічні комплекси, автоматизовані $\begin{array}{llll}\text { системи, розгорнуті в } & \text { ОУ, }\end{array}$ 
тактико-технічних завданнях на створення їх нових дослідних зразків, результатах досліджень розвитку засобів автоматизованого управління військового призначення передових країн світу тощо.

На другому етапі, на підставі результатів аналізу наявної кількості технічних та програмних засобів, встановлених на АРМ посадових осіб ОУ, та необхідної їх кількості, розраховуються відповідні показники рівнів технічного та програмного оснащення АРМ. Дані показники формують узагальнений рівень оснащення технічними та програмними засобами АРM посадових осіб ОУ.

За результатами виконання дослідноконструкторських робіт значення показників рівнів технічного та програмного оснащення АРМ повинні задовольняти вимогам $K_{\text {отз }} \geq 0,8$, а $K_{\text {отз }} \geq 0,7$. Відповідно, узагальнений рівень оснащення технічними та програмними засобами AРМ $K_{\text {отпз }} \geq 0,56$. Цей показник безпосередньо впливає на своєчасність виконання функцій ОУ.

Третій етап методичного підходу передбачає здійснення розрахунку якості оснащення технічними та програмними засобами АРМ посадових осіб ОУ.

Для технічних засобів АРМ розрахунки базуються на визначенні співвідношення наявних показників основних характеристик технічних засобів АРМ до визначених вимогами. Розраховуються окремо рівень відповідності за кожною характеристикою технічного засобу АРМ $(\sigma)$, рівень технічного засобу зі складу АРМ $K_{m з}$, та загальний рівень якості оснащення технічними засобами АРМ, який повинен задовольняти вимозі $K_{\text {тоза }} \geq 0,9$.

Для програмних засобів АРМ посадових осіб ОУ обрані показники: загальний час $T_{\kappa}$, що витрачається на постановку типового завдання (операціі) $t_{k}^{n m 3}$, оброблення даних під час його

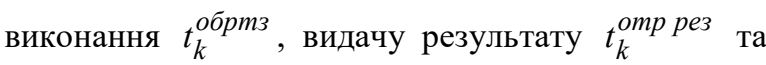
продуктивність програмного забезпечення $C_{\kappa}$, що оцінюється.

Значення вимог до показників якості функціонування програмного забезпечення АРМ повинні становити $T_{\kappa} \leq 100 c, C_{\kappa} \geq 500$ типових завдань за хвилину.

На четвертому етапі методичного підходу здійснюється розрахунок надійності функціонування технічних та програмних засобів АРМ посадових осіб ОУ.

В якості основних характеристик надійності функціонування АРМ обрано безвідмовність функціонування та ремонтопридатність названих його складових. Відповідно, показниками, що характеризують надійність визначено: середній час напрацювання на відмову засобів $T_{\text {відм }}$, середній час, що витрачається на їх відновлення після виникнення відмов $T_{\text {віднов }}$ та коефіцієнт готовності складових АРМ до виконання визначених функцій $K_{\text {гот }}$. При цьому отримані значення показників повинні становити $T_{\text {відм }} \geq 1000$ годин, $\quad T_{\text {віднов }} \leq 10$ хвилин $\quad$ та $K_{\text {гоm }} \geq 0,9$.

На п'ятому етапі методичного підходу передбачається проведення розрахунку ступеня взаємозв'язку АРМ посадових осіб ОУ на пункті управління.

Зазначений розрахунок базується на теорії графів. В якості вершин графу $m_{v}$ визначаються APM ОУ, в якості ребер $m_{l}$ - канали зв'язку між ними. Такий підхід дозволяє розрахувати та оцінити рівень взаємозв'язку АРМ за показником потужності множини графу $m_{d} m_{d}$. Рівень визначається як відношення наявної потужності множини графу до потрібної і повинен складати $M_{d} \geq 0,8$.

На шостому етапі методичного підходу за результатами розрахунків показників, що характеризують рівень оснащення АРМ посадових осіб ОУ технічними та програмними засобами, рівень якості функціонування, надійності та взаємозв'язку АРМ, здійснюється їх порівняння на відповідність вимогам, які до них висунуті. Якщо значення показників не задовольняють висунутим до них вимогам - функції посадових осіб ОУ, які вони характеризують, вважаються неавтоматизованими.

Після цього, відповідно, визначається кількість функцій ОУ $t_{\text {НВавт }}^{f}$, які по ряду причин не задовольняють визначеним до них вимогам як до “автоматизованих". Такі функції вважаються “неавтоматизованими” і під час оцінки рівня автоматизації $K_{\text {авт j }}$ ОУ не враховуються.

\section{Висновки і перспективи подальших досліджень}

Таким чином, розроблений методичний підхід дозволяє на основі обгрунтованих вище математичних співвідношень розрахувати показники, що характеризують рівень оснащення АРМ посадових осіб ОУ технічними, програмними засобами, рівень якості функціонування, надійності, взаємозв'язку АРМ та на їх підставі визначити кількість автоматизованих функцій як на кожному АРМ, так за весь ОУ, в цілому, що забезпечить оцінку рівню автоматизації ОУ.

Перспективним напрямком досліджень в цій галузі $\epsilon$ розвиток наведеного в доповіді методичного підходу через врахування важливості функцій, які автоматизовані. За результатами проведених розрахунків визначити рівень автоматизації ОУ, який дозволить виробити пропозиції щодо його покращення 


\begin{abstract}
Даний підхід був апробований під час наукового супроводження дослідноконструкторських робіт, технічного проектування та розроблення робочої конструкторської документації на автоматизовану систему
\end{abstract}

управління та ряду завдань пов'язаних 3 формуванням оперативно-тактичних вимог до перспективних автоматизованих систем управління військами (силами).

\title{
Jimepamypa
}

1. Алтухов П. К. и др. Основы теории управления войсками. Москва: Воениздат, 1984. 221 с. 2. Выпасняк В.И. Автоматизированные системы управления войсками (силами): тенденции, методы и перспективы развития / В.И.Выпасняк, О.В.Тиханычев // Весник академии воєнних наук, 2009. - № 4 (29). - С. 64 - 69 . 3. Линник Е.А. Выбор тактических характеристик в качестве показателей эффективности функцыионирования автоматизированных систем управления родами авиации /Е.А.Линник, А.В.Шамарин, Д.А.Чистилин // Воздушно-космические силы. Теория и практика, 2017. - №1. - С. 41 - 50 4. Герасимов Б.М. Методика оцінки ефективності автоматизованої системи підтримки інформаційноаналітичної роботи / Б.М.Герасимов, О.М.Перегуда, І.А.Круковський // Зб. наук. пр. НТУ України “КПІ”. Вип. 3. 2008. 154 c.

\section{МЕТОДИЧЕСКИЙ ПОДХОД К ОЦЕНИВАНИЮ УРОВНЯ АВТОМАТИЗАЦИИ РАБОТЫ ОРГАНОВ УПРАВЛЕНИЕ}

\author{
Сергей Александрович Кирсанов (канд. техн. наук, с.н.с) \\ Сергей Николаевич Островский
}

\section{Центральный научно-исследовательский институт Вооруженных Сил Украины, Киев, Украина}

В статье изложен методчческий подход, который позволяет рассчитать количество автоматизированных функиий на каждом автоматизированном рабочем месте и за весь орган управления, в целом, с неуклонным соблюдением определенных требований к показателям: уровня оснащения его техническими и программными средствами, уровня качества их функционирование, надежности и взаимосвязи АРМ

Ключевые слова: автоматизированное рабочее место; технические и программные средства; надежность функционирования; уровень автоматизации задач органов управления.

\section{METHODICAL APPROACH TO EVALUATION OF THE LEVEL OF AUTOMATION OF OPERATIONS OF MANAGEMENT AUTHORITIES}

\author{
Sergiy O. Kirsanov (Candidate of Technical Sciences, Senior Researcher) \\ Sergiy M. Ostrovskiy \\ Central Research Institute of the Armed Forces of Ukraine, Kyiv, Ukraine
}

The article outlines a methodical approach that allows to calculate the number of automated functions at each automated workplace (AWP) and for the entire management authorities (MA), in general, with strict compliance with the specified requirements for indicators: the level of equipment with its technical and software tools, the quality level their functioning, reliability and interconnection of AWP.

Keywords: automated workplace; technical and software tools; reliability of functioning; the level of automation of tasks of management authorities.

\section{References}

1. Altukhov P. K. and others. Fundamentals of the theory of troop control [osnovy upravlenija voiskami]. Moscow: Mill.publication, 1984. 221 p. 2. Vypasniak V.I. Automated control system: tendencies, methods and perspectives of development/ V.I.Vypasniak, O.V.Tihanichev // Coll. of the science academy, 2009. - № 4 (29). - P. 64 - 69/ 3. Linnic E.A. The choice of the technical characteristic as indexes of effectiveness of the functioning automated systems of the aviation branch control
/E.A.Lynnyk, A.V.Shamarin, D.A.Chistilin // Air-Cosmics Forces. Theory and Practice. 2017. - №1. - P. 41 - 50/ 4. Gerasimov B.M. Methodology for evaluating the effectiveness of an automated system for supporting information and analytical work / B. M. Gerasimov, A. M. Pereguda, I. A. Krukovskii // Coll. of sciences of National Technical University of Ukraine "KPI". № 3.2008. 154 p. 